\title{
意䇅データを用いた非集計モデルの

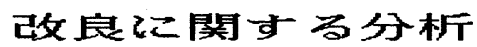

\author{
Improvement of Disaggregate Models by Using Attitudinal Data \\ for Travel Choice Prediction
}

鈴木 聡 ${ }^{*}$. 原田 昇 ${ }^{* *}$. 太田勝敏 ${ }^{* * *}$

By Satoshi SUZUKI, Noboru HARATA and Katsutoshi OHTA

\begin{abstract}
This paper presents attempts to improve some defects of conventional disaggregate models by using attitudinal data for travel choice prediction. Our first approach is the use of attitudinal data as explanatory variables for qualitative factor. The second approach is it's use as an index for segmentation to consider variation of individual decision criteria. Our conclusions are as follows. As explanatory variables evaluated values and reported values of LOS variables have good explanatory power and evaluated values, in particular, have ability to explain qualitative factor. The segmentation based on whether person evaluates highly the delay of travel time or not is effective in explaining variation of individual choice.
\end{abstract}

\section{1.はじめに}

交通需要予測モデルとしては、従来のパーソント リップ調査をベースとする4段階推定法に加えて、 効用最大化理論に基づき個人の選択行動に注目した 非集計モデルが提案され、1970年代以降、手段選択 ・目的地選択・経路選択などについて数多くの研究 がなされてきた。しかしながら、4段階推定法と比 べて多くの利点を持つとされる非集計モデルにおい ても、個人による評価指標の相違及びそのウェイト の相違が考虑しにくい"、交通サービス特性として 時間や料金など定量的指標しか用いられず、混雑や 車内環境としての快適性など定性的な要因が考慮し にくいなど様々な問題点が指摘されている。これら

\footnotetext{
* 学生員 工修 東京大学大学院 工学部都市工学科 (テ 1 1 13 文京区本郷 7-3-1)

** 正会員 工博 東京大学助手

*** 正会員 Ph.D. 東京大学助教授
}

の問題点に対して、意識データ(Attitudinal data) を用いるというアプローチより解決を試みるのが本 研究の目的である。

\section{2. 研究の背景と本研究のアプローチ}

\section{（1）意識デー夕の分類と定義}

モデルの説明変数は図 1 に示すように、個人の特 性を表わす指標と交通サービス指標の 2 種類に分類 され、それぞれに主観的なむのが存在するものと考 える。まず、個人の特性を表わす指標としては、年 令や職業などの社会経済属性と、車や免許の保有と いう車の利用可能性などの利用可能交通手段に客観 的な個人の特性が表わされ、一方、交通サービスレ ベルに対する満足度としての評価と、時間重視か、 あるいは、料金重視かという交通サービス指標の重 視度などには、個人の主観的な特性が表わされるも のと考える。

交通サービス指標としては、データの性質から、 
測定値、設定値、回答値、評価値の 4 種類に分けら れる。例えば、個人のトリップの所要時間や待ち時 間などを現場で直接測定するのが測定值であり、設 定値とは、分析者が統一された客観的な判断基準に 従って、個人のトリップの所要時間や待ち・乗換・ 徒歩時間などを設定するものであり、こ机らには個 人の意識が入らないということで、ここでは客観値 とする。回答値とは、アンケート調査の所要時間は 何分ですかという質問に対する回答値であり、評価 值とは同様に所要時間に対しての满足度としての評 洒值であり、これらには個人の判断に基づくことに よる個人変動が含まれるので主観値とする。

以上のような客観值と主観值という分類の他に、 定量的か定性的かという分類を試みると、測定値 設定值・回答値は、時間や料金など明確な測定の尺 度が存在する指標についてしか得られないのに対し て、評価値はこうした定量的な指標についても得ら れるばかりでなく、車内の快適性はどうかという定 性的な指標についても捉えられるという特徵がある。

（2）意識デー夕を用いた既存研究のレビュー 従来の非集計モデルでは、交通サービス指標とし て設定値または回答値のどちらか一方、個人特性と しては客観值を用い、一般的なAtti tude-Behaviour モデルでは、交通サービスの評価値をそのまま説明 変数として用いたり、評価值の因子分析を行なった 後にその因子スコアを用いており、315さらにこれ らの評価値に個人特性として主観値を加えることも ある。また、河上らの「主観値を考慮した非集計モ デル」2では、利用手段による評価構造の相違を考 慮し、利用手段別に求めた総合的評価値と個人特性 の客観值を用いている。それぞれのアプローチにつ いて長所や短所があるものの、全体としては、設定 值・回答値・評洒値の3者の関係が明確にされてい

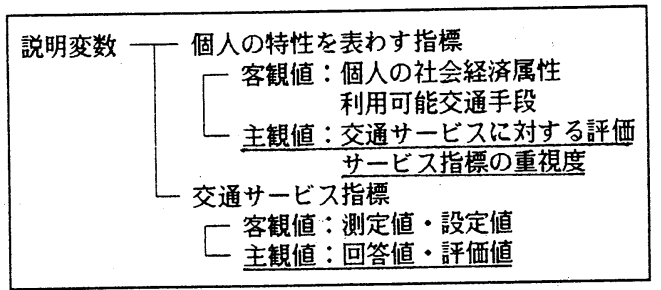

図 1. 説明変数の分類と定義(下線部を意識テータとする)
ない点が問題と考えられる。

以上とは別の視点として、個人特性をモデルに説 明変数として人れるのか、岁るいは、七グメントに 用いるのかという点が苟る。従来では、個人特性の 客観値を多ミー変数としてモデルに入れたり、客観 值によるセグメント別に予測が行なわれているが、 通勤や通学の交通手段選択では、個人特性としての 客観値はあまり説明力を持たないという問題点があ る。るうした客観値の代わりに、個人特性の主観値 である評価値の差、あるいは、評価値を因子分析し た因子スコアなどを用いたクラスター分析を行うと、 そのセグメントにより個人の社会経済属性、利用の 意向、選択行動などが異なることは明らかにさ机て いるが、これらの主観値によるセグメント別モデル の予測は行なわれていない。4)6

(3) 具体的な分析項目

以上のような点を考慮して、以下の 3 点について 分析を行なう。

(1)回答值を説明変数としたモデルと設定値を説明変 数とした従来型モデルの比較

(2)交通サービスに対する評価值を従来型モデルに追 加したモデルと、従来型モデルの比較

(3)セグメントに用いる指標としての主観値と客観值 の比較

\section{（4）分析に用いたデータの概要}

調査対象地域は、昭和60年 3 月に開業した横浜市 営地下鉄 3 号線（横浜～新横浜間）の片倉町駅勢圈 を中心とした地域であり、調査対象は通勤・通学行 動である。分析に用いたのは、事前・事後調査のう ちの事後調査のデータであり、開業から約半年経過 した昭和60年 9 月末から10月中旬にかけて実施し、 世帯ベースで871票、個人ベースて1201票が回収さ

\section{表 1. 主な調査項目}

*地下鉄を利用する場合の交通手段及び経路 *地下鉄を利用しない場合の交通手段及び経路 *両経路に対する総所要時間、乗車・待ち・乗換・徒歩 時間、所要時間の荤れ及び利用頻度と混み具合 *両経路の経路全体の総合的な满足度 ( 5 段階)及び13の 個別の交通サービス指標に対する满足度 ( 5 段階) *13の交通サービス指標の重視度 *個人の社会経済属性（年令・性別・世帯の年収） 


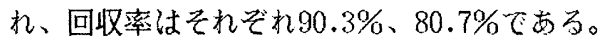

主な調査内容は表 1 亿示すように、地下鉄を利用 する場合の経路と地下鉄を利用しない場合の経路に 注目して、それぞれの利用状況、回答值としての所 要時間や乗車時間など、各交通サービス指標に対す る評価値としての渵足度、選択の際に重視する交通 サービス指標などとした。

\section{3 . 基礎的な分析}

\section{（1）従来型モデル}

分析の対象は鉄道の経路選択として、地下鉄を利 用する経路と地下鉄を利用しない経路の両方を回答 しており、かつ、地下鉄を利用しない経路の代表手 段が鉄道て、どちらかの経路を主に利用しているサ ンプルを抽出したところ 428 サプルとなった。こ れらのサンプルに対して、乗車時間や料金などの交 通サービス変数を、自宅から共通駅までについて設 定し、線形効用関数を仮定して最尤法により、地下 鉄を利用する経路と地下鉄を利用しない経路の二項 ロジットモデルのパラメー夕を推定した。トリップ 目的別の推定結果婊 2 に示す通りである。

乗換・待ち時間以外は、いずれのモデルでも $t$-値 と符号条件を満足しているが、乗換・待ち時間は、 通勤モデルで有意水準を満たすものの、通学モデル ではt值が 0 に近く、そのために通勤・通学でもt 值が多少悪くなり、パラメータが安定しない結果と なっている。モデルの説明力は、通勤・通学モデル で的中率 $74 \%$ 、尤度比 0.2316 、通勤モデルで的中率

表 2. 従来型モデルのトリッブ目的別推定結果 [t-值 $]$

\begin{tabular}{|c|c|c|c|}
\hline & 通勤通学 & 通勤 & 通学 \\
\hline 料金 & -0.0161 & -0.0148 & -0.0196 \\
& {$[-4.46]$} & {$[-3.39]$} & {$[-2.54]$} \\
乗換・待ち時間 & -0.0663 & -0.0970 & 0.0237 \\
徒歩時間 & {$[-1.72]$} & {$[-2.05]$} & {$[0.34]$} \\
& {$[-6.2349$} & -0.2392 & -0.2214 \\
原付等乗車時間 & -0.3208 & {$[-6.23]$} & {$[-2.60]$} \\
バス乗車時間 & -0.3084 & -0.3269 \\
& {$[-7.58]$} & {$[-2.81]$} & {$[-3.01]$} \\
鉄道乗車時間 & -0.1631 & -0.1792 & -0.1642 \\
& {$[-5.13]$} & $-0.85]$ & {$[-3.21]$} \\
\hline 的中率 & $74.07 \%$ & $73.73 \%$ & -0.1803 \\
$\rho^{2}$ & 0.2316 & 0.2398 & $0.2197]$ \\
サンブル数 & 428 & 335 & $97.42 \%$ \\
\hline
\end{tabular}

$74 \%$ 、尤度比0.2398、通学モデルて的中率77\%、尤 度比0.2199であり、通学モデルでは尤度比の低下が 加ら机る。

統計的に㫑適合度を重視すると通学モデルにつ いては疑問が残るため、以後の分析において比較の 基礎となる従来型モデルは通勤モデルとし、このモ デルに評価值を追加したモデル、セグメント別のモ デルなどの検討を行なう。

（2）設定值・回答值・評価値の関係

モデルによる比較の前にあらかじめ、設定値、回 答值、評価値の関係を分析する。総所要時間、乗車 時間、待古時間、乗り換元時間、徒歩時間、所要時 間の遅れ、料金の7種類を対象とするが、すべての 変数汶対して、設定值、回答值、評価値が得られて いるわけではない。

設定值が自宅から共通駅までの值であるのに対し て、回答值と評価値は経路全体についての值である ため、地下鉄を利用する経路と地下鉄を利用しない 経路との差を分析するものとする。また、回答値と 評価値については、両方の経路についての回答が得

表 3 . 各変数の基本統計量

\begin{tabular}{|c|c|c|c|c|c|}
\hline \multicolumn{2}{|c|}{$\begin{array}{l}\text { 変数の種類 } \\
\text { (サンブル数) }\end{array}$} & 最大値 & 最小值 & 平均値 & 標準偏差 \\
\hline $\begin{array}{c}\text { 総所要時間 } \\
(241)\end{array}$ & $\begin{array}{l}\text { 設定値 } \\
\text { 回答値 } \\
\text { 評佂伯 }\end{array}$ & $\begin{array}{r}31 \\
50 \\
4\end{array}$ & $\begin{array}{r}-19 \\
-50 \\
-4\end{array}$ & $\begin{array}{l}3.24 \\
4.54 \\
1.48\end{array}$ & $\begin{array}{r}7.143 \\
14.413 \\
2.208\end{array}$ \\
\hline $\begin{array}{c}\text { 乗車時間 } \\
(304)\end{array}$ & $\begin{array}{l}\text { 設定値 } \\
\text { 回答値 } \\
\text { 評価値 }\end{array}$ & $\begin{array}{r}20 \\
40 \\
---\end{array}$ & $\begin{array}{l}-20 \\
-35 \\
---\end{array}$ & $\begin{array}{l}6.23 \\
6.70 \\
-\end{array}$ & $\begin{array}{r}6.351 \\
11.315 \\
\end{array}$ \\
\hline $\begin{array}{c}\text { 待ち時間 } \\
(244)\end{array}$ & $\begin{array}{l}\text { 設定値 } \\
\text { 回答値 } \\
\text { 評価値 }\end{array}$ & $\begin{array}{r}10 \\
20 \\
4\end{array}$ & $\begin{array}{r}-10 \\
-15 \\
-4\end{array}$ & $\begin{array}{l}0.50 \\
1.04 \\
1.59\end{array}$ & $\begin{array}{l}2.680 \\
4.493 \\
1.964\end{array}$ \\
\hline $\begin{array}{c}\text { 乗換時間 } \\
(218)\end{array}$ & $\begin{array}{l}\text { 設定値 } \\
\text { 回答値 } \\
\text { 評価値 }\end{array}$ & $\begin{array}{r}4 \\
10 \\
4\end{array}$ & $\begin{array}{l}-10 \\
-11 \\
-4\end{array}$ & $\begin{array}{l}-0.89 \\
-1.08 \\
-0.49\end{array}$ & $\begin{array}{l}2.105 \\
3.257 \\
1.737\end{array}$ \\
\hline $\begin{array}{c}\text { 徒歩時間 } \\
\text { (267) }\end{array}$ & $\begin{array}{l}\text { 設定値 } \\
\text { 回答値 } \\
\text { 評価値 }\end{array}$ & $\begin{array}{r}24 \\
25 \\
4\end{array}$ & $\begin{array}{r}-14 \\
-28 \\
-4\end{array}$ & $\begin{array}{l}-3.18 \\
-2.72 \\
-1.02\end{array}$ & $\begin{array}{l}5.283 \\
5.975 \\
2.010\end{array}$ \\
\hline $\begin{array}{l}\text { 所要時間の } \\
\text { 荤れ(286) }\end{array}$ & $\begin{array}{l}\text { 設定値 } \\
\text { 回答値 } \\
\text { 評価値 }\end{array}$ & $\begin{array}{r}--- \\
30 \\
4\end{array}$ & $\begin{array}{l}--- \\
-30 \\
-4\end{array}$ & $\begin{array}{l}-.- \\
2.76 \\
2.30\end{array}$ & $\begin{array}{l}7.575 \\
1.753\end{array}$ \\
\hline 料金 (288) & $\begin{array}{l}\text { 設定値 } \\
\text { 回答値 } \\
\text { 評洒値 }\end{array}$ & $\begin{array}{r}84 \\
-- \\
4\end{array}$ & $\begin{array}{r}-157 \\
--4\end{array}$ & $\begin{array}{r}-1.00 \\
-0.58\end{array}$ & $\frac{17.510}{1.769}$ \\
\hline
\end{tabular}

注. 各变数は両経路の差(地下鉄でない経路一地下鉄経路) 評価値は、5段階の满足度である。 


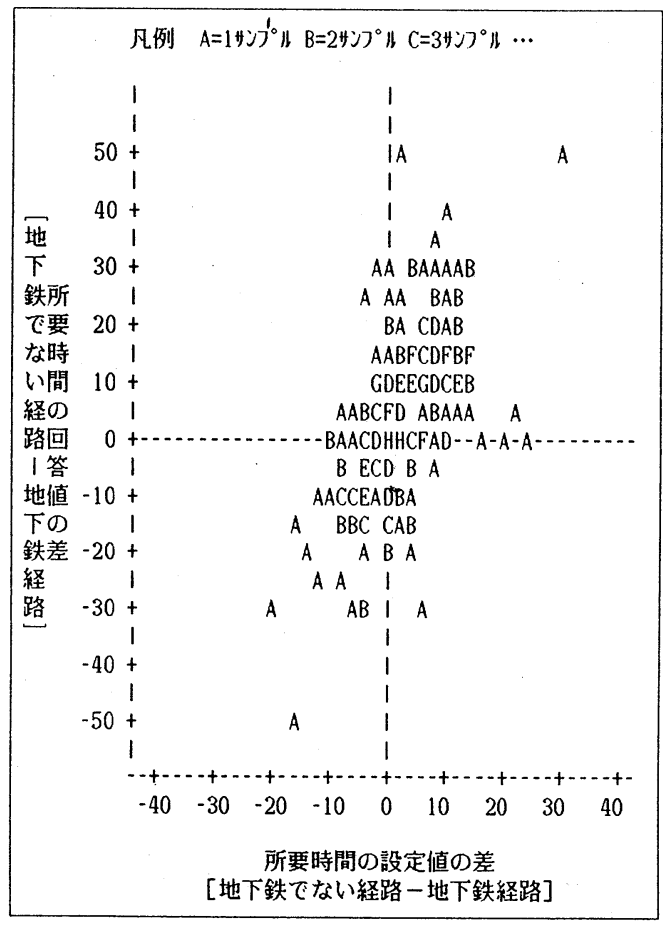

図2、設定值と回答値の関係

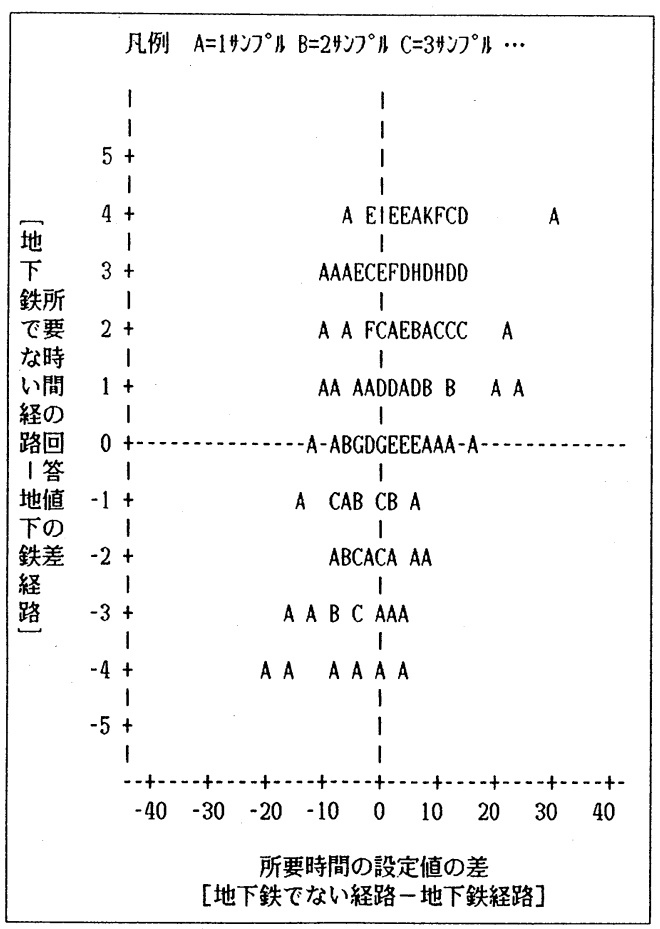

図3．設定値と評価値の関係
られていることが必要であり、各変数について両方 の経路に関する回答值と評価值が得られている、通 勤目的のサンプルを抽出して分析を行なったため、 変数によりサンプル数が異なっている。

各変数の基本統計量として、最大值と最小値、平 均と標準偏差をまとめたのが表 3 である。最大值と 最小值、標準偏差の値で判断すると、設定值と比較 して回答値はかなりバラツキが大きい。特に、総所 要時間と乗車時間と待ち時間については、設定値と 比べて回答值は約 2 倍程度のバラツキとなる。とこ ろが、徒歩時間については、平均と標準偏差が活活 等しく、似たような分布となっていることが分かる。 所要時間について、設定值と回答值、設定值上評価 值の関係を示したのが図2と図3であるが、多少の バラツキは見られるものの、全体では斜めの直線を 軸として、比較的にまとまっていると考えられる。

設定値と回答値、設定値と評価值、回答值と評価 值についての単相関係数とその有意性確率をまとめ たのが、表 4 であるが、全体としては高い相関を示 し、特に徒歩時間と総所要時間で相関が高い。しか しながら、待ち時間と乗換時間については、設定値 と回答値、設定値と評価値の相関が低く、運行間隔 の $1 / 2$ とした待ち時間の設定方法、駅別に設定し た乗換時間の設定方法に問題があったと考えられる。

表 4. 変数閒の単相関係数 [有意性確宰]

\begin{tabular}{|c|c|c|c|}
\hline $\begin{array}{c}\text { 変数名 } \\
\text { （サンブル数） }\end{array}$ & $\begin{array}{c}\text { 設定値 } \\
\text { vs. } \\
\text { 回答値 }\end{array}$ & $\begin{array}{c}\text { 設定値 } \\
\text { vs. } \\
\text { 評洒値 }\end{array}$ & $\begin{array}{c}\text { 回答值 } \\
\text { vs. } \\
\text { 評価値 }\end{array}$ \\
\hline $\begin{array}{l}\text { 総所要時間 } \\
(241)\end{array}$ & $\begin{array}{c}0.594 \\
{[0.0001]}\end{array}$ & $\begin{array}{c}0.460 \\
{[0.0001]}\end{array}$ & $\begin{array}{c}0.633 \\
{[0.0001]}\end{array}$ \\
\hline $\begin{array}{c}\text { 乗車時間 } \\
(304)\end{array}$ & $\begin{array}{c}0.564 \\
{[0.0001]}\end{array}$ & & \\
\hline $\begin{array}{c}\text { 待ち時間 } \\
(244)\end{array}$ & $\begin{array}{c}0.135 \\
{[0.0350]}\end{array}$ & $\begin{array}{c}0.186 \\
{[0.0036]}\end{array}$ & $\begin{array}{c}0.425 \\
{[0.0001]}\end{array}$ \\
\hline $\begin{array}{c}\text { 乗換時間 } \\
(218)\end{array}$ & $\begin{array}{c}0.151 \\
{[0.0256]}\end{array}$ & $\begin{array}{c}0.150 \\
{[0.0272]}\end{array}$ & $\begin{array}{c}0.416 \\
{[0.0001]}\end{array}$ \\
\hline $\begin{array}{c}\text { 徒歩時間 } \\
\text { (267) }\end{array}$ & $\begin{array}{c}0.614 \\
{[0.0001]}\end{array}$ & $\begin{array}{c}0.533 \\
{[0.0001]}\end{array}$ & $\begin{array}{c}0.642 \\
{[0.0001]}\end{array}$ \\
\hline $\begin{array}{c}\text { 所要時間の遧机 } \\
(286)\end{array}$ & ........... & (n. & $\begin{array}{c}0.312 \\
{[0.0001]}\end{array}$ \\
\hline $\begin{array}{l}\text { 料金 } \\
\text { (288) }\end{array}$ & , & $\begin{array}{c}0.310 \\
{[0.0001]}\end{array}$ & $\cdots$ \\
\hline
\end{tabular}

注. 各変数は両経路の差(地下鉄でない経路一地下鉄経路) 
また、徒歩時間と総所要時間を含む全ての変数で、 設定値よりも回答值の方が評価值との相関が高く、 回答値には個人の主観の影響が認められる。

\section{4. 意識データの有効性の検討}

（1）従来型モデルと回答値モデルの比較

モデルの説明変数として、回答值を用いた場合と 一般的に利用される設定值を用いた場合にどれだけ の相違が見られるかを、純粋に検討するために共通 のデータを用いるものとする。そのために、回答值 として、所要時間、乗車時間、待ち時間については、 どちらか一方の経路で0ならば分析対象から除き、 乗換時間については各経路で乗換をしているにもか かわらず乗換時間が 0 のケースを除いたところ、約 半数の 234 サンプルとなった。

パラメータの推定結果は表 5 に示す通りで、説明 変数の組み合わせとしては、上段は時間を所要時間 としてまとめ、下段は乗車時間、待ち時間、乗換 待ち時間、徒歩時間などの個別の時間としたもので ある。これらの変数の内、料金については回答值が 得られていないので、どちらのモデルでも設定值を

表 5. 従来型モデルと回答値モデルの比較 [t-值 $]$

\begin{tabular}{|c|c|c|c|}
\hline \multicolumn{2}{|c|}{ 従来型モデル } & \multicolumn{2}{|c|}{ 回答値モデル } \\
\hline 料金 + & -0.0166 & 料金+ & -0.0200 \\
\hline & -0.0966 & & -0.0833 \\
\hline 所要時間の遅机* & {$[-3.58]$} & 所要時間の遅れ* & {$[-2.86]$} \\
\hline 総所要時間+ & $\begin{array}{c}-0.1648 \\
{[-5.39]}\end{array}$ & 総所要時間* & $\begin{array}{c}-0.1072 \\
{[-6.34]}\end{array}$ \\
\hline 的中率 & $76.50 \%$ & 的中率 & $84.19 \%$ \\
\hline$\rho^{2}$ & 0.3462 & $\rho^{2}$ & 0.4246 \\
\hline 料金+ & -0.0336 & 料金十 & -0.0191 \\
\hline 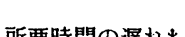 & -0.1135 & & -0.1108 \\
\hline 所要時間の羊扎* & {$[-3.74]$} & 所要時間の羊れれ & {$[-3.28]$} \\
\hline 乗换 - 待ち時間+ & $\begin{array}{c}-0.0845 \\
{[-1.36]}\end{array}$ & 乗換時間* & $\begin{array}{c}-0.2403 \\
{[-3.60]}\end{array}$ \\
\hline 徒歩時間+ & -0.2876 & 待ち時間* & -0.1820 \\
\hline & {$[-5.17]$} & & {$[-3.39]$} \\
\hline 原付等乗車時間+ & $\begin{array}{l}-0.4104 \\
\Gamma-3.237\end{array}$ & 徒歩時間* & $\begin{array}{l}-0.1442 \\
{[-4.101}\end{array}$ \\
\hline バ乙垂本晆聞十 & -0.1763 & 垂車晆問； & -0.0840 \\
\hline 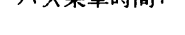 & {$[-3.52]$} & 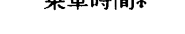 & {$[-4.49]$} \\
\hline 鉄道乗車時間+ & $\begin{array}{c}-0.1778 \\
{[-5.17]}\end{array}$ & n. & (n....... \\
\hline $\begin{array}{c}\text { 的中率 } \\
\rho^{2}\end{array}$ & $\begin{array}{l}81.20 \% \\
0.3855\end{array}$ & $\begin{array}{c}\text { 的中率 } \\
\rho^{2}\end{array}$ & $\begin{array}{l}84.62 \% \\
0.4708\end{array}$ \\
\hline
\end{tabular}

注. 両経路の回答值が得られている234サンブルで比較 $*$ : 回答値、 + : 設定值
用い、逆に、所要時間の遅れについては設定するこ とが不可能で回答值しかないのでどちらのモデルに おいても回答值を用いている。その他の変数につい ては、回答値が得られているので、それぞれに対応 する設定值を用いた。

回答值モデルでは、すべての変数が有意になって おり、総所要時間を用いた場合で、的中率 $84 \%$ 、尤 度比0.4246、個別の時間を用いた場合で、的中率85 \%、尤度比0.4708となっており、モデルの説明力が かなり高くなっている。

一方、設定值を用いた従来型モデルでは、乗換・ 待ち時間のt-值が多少小さいが、他の変数はすべて 有意水準を満たしている。総所要時間を用いた場合 で、的中率77\%、尤度比 $0.3462 、$ 個別の時間用い た場合で、的中率 $81 \%$ 、尤度比 0.3855 となっている。

回答値モデルと設定値を用いた従来型モデルの比 較としては、いずれの場合も回答值モデルの方が説 明力が高くなっているが、この理由としては、両方 の経路についてきちんと乗車時間や乗換時間などを 答えられるような人は、両方の経路についてその個 人なりに情報を持っており、それに基づき合理的選 択を行なっているためと考えられる。

（2）従来型モデルと評価値追加モデルの比較 評価値としては総合的な満足度と個別の満足度の 2 種類を考え、すべてに共通のデー夕を用いて純粋 な比較をするために、総合的な満足度と13の個別の 交通サービス指標に対する満足度を両方の経路につ いてすべて回答しているサンプルを抽出したところ 225サンプルとなった。なお、評価值については、 5 段階の満足度の値（1～5 の数字）をそのままモ デルに追加した。

設定値を用いた従来型モデルにそれぞれの評価值 を追加した場合の、評価值のパラメータとt-值、モ デルの説明力として的中率と尤度比、変数追加の有 意性を示す $\chi^{2}$-值の一覧を示したのが表 6 である。 変数追加の有意性の検定では、(1)式より求めら れる $\chi^{2}$-值が、(2)式で与えられる2つのモデルの 自由度の差（ここでは 1 変数を追加するケースなの で 1 となる）に対応する $\chi^{2}$-值（有意水準 $1 \%$ では 6.63、5\%では3.84）より大きければ、追加した変 数は意味があるものと判定される。 


$$
\begin{gathered}
\chi^{2}\left(k, k^{\prime}\right)=-2\left\{\mathrm{~L}_{k}(\hat{\theta})-\mathrm{L}_{k} \cdot(\hat{\theta})\right\} \quad(1) \\
\mathrm{L}_{k}(\hat{\theta}): k^{\prime} \text { 個の変数のモデルの最尤推定量 } \\
\mathrm{L}_{k} \cdot(\hat{\theta}): \mathrm{k}^{\prime} \text { 個の変数のモデルの最尤推定量 } \\
\text { d.f. }\left(k, k^{\prime}\right)=(\mathrm{N}-\mathrm{k})-\left(\mathrm{N}-\mathrm{k}^{\prime}\right) \quad(2) \\
\mathrm{N}: \text { サンプル数 }
\end{gathered}
$$

表6によると、評洒值を追加する効果が最も大き いのは所要時間に対する評価值であり、半数以上が $1 \%$ 有意で、 $5 \%$ 有意が2つ、5\%有意でないのは 3つにすぎない。しかしながら、評価値を追加する

\begin{tabular}{|c|c|c|c|c|c|}
\hline \multirow{2}{*}{ 追加する評価指標 } & \multirow{2}{*}{$n^{\circ} 5 x-y$} & \multirow{2}{*}{ [t-值] } & \multicolumn{2}{|c|}{ モデルの説明力 } & \multirow{2}{*}{$\chi^{2}$-值 } \\
\hline & & & 的中率 & $\rho^{2}$ & \\
\hline 総合的な满足度 & -1.022 & {$[-6.76]$} & $84.89 \%$ & 0.4944 & $80.3 *$ \\
\hline 費用が & -0.644 & {$[-4.80]$} & $80.89 \%$ & 0.3370 & $31.2 *$ \\
\hline 所要時間が短い & -1.045 & {$[-6.73]$} & $86.67 \%$ & 0.5039 & $83.3 *$ \\
\hline 待ち時間が短い & -0.682 & {$[-5.92]$} & $82.22 \%$ & 0.3900 & $47.7 *$ \\
\hline 歩く距離が短い & -0.164 & {$[-1.56]$} & $74.22 \%$ & 0.2452 & 2.6 \\
\hline 決まった時刻に迋れない & -0.753 & {$[-5.37]$} & $78.67 \%$ & 0.3665 & $40.4 *$ \\
\hline 乗り換えがしやすい & -0.454 & {$[-4.12]$} & $77.33 \%$ & 0.3022 & $20.4 *$ \\
\hline 乗り換え回数が少ない & -1.103 & {$[-4.24]$} & $78.67 \%$ & 0.3435 & $33.2 *$ \\
\hline 階段の昇り降りがしやすい & -0.153 & {$[-1.38]$} & $74.22 \%$ & 0.2435 & 2.0 \\
\hline 乗り降りがしやすい & -0.617 & {$[-4.31]$} & $76.89 \%$ & 0.3160 & $24.6 *$ \\
\hline 騒音など車内の環境が良い & -0.258 & {$[-2.23]$} & $72.44 \%$ & 0.2540 & $5.4+$ \\
\hline ブライバシーが守られる & -0.330 & {$[-2.24]$} & $74.22 \%$ & 0.2553 & $5.8+$ \\
\hline 雨天時に利月 & -0.237 & {$[-2.62]$} & $74.22 \%$ & 0.2606 & $7.4 *$ \\
\hline 事故・犯罪の恐れがない & -0.093 & {$[-0.65]$} & $72.44 \%$ & 0.2386 & 0.4 \\
\hline
\end{tabular}
効果が大きいのは、定量的要因がほとんどであり、 定性的要因の効果はあまり大きくない。これは、設 定值と意識との差が大きく、行動が意識に基づいて

表6. 従来型モデルに各評価値を加えた場合の比較

注. * : $1 \%$ 有意 + : $5 \%$ 有意

評価値については、5段階の满足度の値をそのまま追加している

表7. 従来型モデルに評洒値を加えたモデルのバラメータの比較 [t-值]
なされていることを示唆していると考えられる。 総合的な满足度と、定量的・定性的要因の中で最 む効果が大きい、所要時間が短い、乗り降りがしや すいについて、パラメータの比較を行ったのが表 7 である。

両方の経路の総合的な満足度を、設定値による従 来型モデルに追加すると、モデルの説明力は大幅に 上昇し、的中率が85\%、尤度比0.4944となるものの、 乗車時間の $\mathrm{t}$-值が小さくなる。また、定量的要因と して「所要時間が短い」についての評価値を追加す 万と、的中率 $87 \%$ 、尤度比 0.5039 と説明力は非常に 良くなり、 $\chi^{2}$-検定でも $1 \%$ 有意水準を満たすむ のの、評価値の効果が大きく、評洒值 と相関を持つ乗車時間のt-值が小さく なり、中でもバス乗車時間については ほとんど意味を持たなくなる。一方、 定性的要因として「乗り降りがしやす いについての評価値を加えると、的 中率が77\%、尤度比0.3160とモデルの 説明力が改善され、 $\chi^{2}$-検定でも $1 \%$ の有意水準を満たし、定量的要因ほど ではないものの、評価値を追加する効 果があることがわかる。さらに、従来 型モデルとパラメータを比較してもほ

\begin{tabular}{|c|c|c|c|c|}
\hline & \multirow{3}{*}{ 従来型モデル } & \multicolumn{3}{|c|}{ 評価值を加えたモテル } \\
\hline & & \multirow{2}{*}{$\frac{\text { 全体の評価值 }}{\text { 総合的満足度 }}$} & \multicolumn{2}{|c|}{ 個別の交通サービスに対する評価値 } \\
\hline & & & $\begin{array}{c}\text { 定量的要因 } \\
\text { 所要時間が短い }\end{array}$ & $\begin{array}{c}\text { 定性的要因 } \\
\text { 乗り降りが容易 }\end{array}$ \\
\hline $\begin{array}{c}\text { 乗換・待ち時間 } \\
\text { 徒歩時間 } \\
\text { 原付等乗車時間 } \\
\text { 鉄道乗車時間 } \\
\text { バス乗車時間 } \\
\text { 評価値 }\end{array}$ & $\begin{array}{l}-0.2183[-4.74] \\
-0.1639[-3.85] \\
-0.2537[-2.24] \\
-0.2094[-4.36] \\
-0.1945[-6.26]\end{array}$ & $\begin{array}{l}-0.1438[-2.70] \\
-0.1126[-2.19] \\
-0.2141[-1.22] \\
-0.0849[-2.26] \\
-0.2134[-3.60] \\
-1.022[-6.76]\end{array}$ & $\begin{array}{l}-0.1906[-3.33] \\
-0.1356[-2.51] \\
-0.3845[-1.81] \\
-0.1000[-1.68] \\
-0.0136[-0.33] \\
-1.045[-6.73]\end{array}$ & $\begin{array}{l}-0.2110[-4.36] \\
-0.1645[-3.57] \\
-0.3364[-2.93] \\
-0.2137[-4.17] \\
-0.1917[-5.73] \\
-0.6171[-4.31]\end{array}$ \\
\hline $\begin{array}{c}L(\hat{\theta}) \\
\chi^{2}-\text { 值 } \\
\text { 的中率 } \\
\rho^{2}\end{array}$ & $\begin{array}{l}-119.0 \\
73.33 \% \\
0.2371\end{array}$ & $\begin{array}{r}-78.9 \\
80.3 * \\
84.89 \% \\
0.4944\end{array}$ & $\begin{array}{r}-77.4 \\
83.3 * \\
86.67 \% \\
0.5039\end{array}$ & $\begin{array}{r}-106.7 \\
24.6 * \\
76.89 \% \\
0.3160\end{array}$ \\
\hline
\end{tabular}
ぼ安定しており、全ての変数のt-值も 2 以上であり、従来型モデルでは説明 していなかった定性的要因が新たに考 慮されるようになったことがわかる。

注. 両方の経路について評価値の得られた225サンブルで比較［*：1\%有意] 
（3）主観値・客観値によるセグメントの比較

客観的指標として年令と性別、主観的指摽として、 遅れを重視するかどうか、地下鉄でない経路に不满 かどうかを取り上げ、セグメントの指標としての主 観的指標の有効性を検討する。

各セグメントの的中率と尤度比、および、サンプ ル数で重みづけした全体の的中率と尤度比、セグメ ント別の地下鉄経路の予測シェアとサンプル数で重

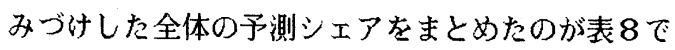
ある。

客観値の性別と40才で区切った年令については、 重みづけした説明力も従来型モデルとほとんど変わ らず、一方のセグメントについては、効果があるむ のの、他方のセグメントでは逆に説明力が落ちてい る。30才で区切った年令については、重みづけした

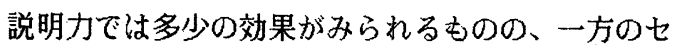
グメントだけ効果がみられるのは、性別や40才を区 切りとした年令と同様である。

主観値の方では、遅れの重視度によるセグメント の効果が大きく、いずれのセグメントについてむ尤 度比が0.32以上となっており、重みづけした的中率 80\%、尤度比0.3343となっている。地下鉄でない経 路についての満足度によるセグメントでは、不満で あるセグメントでは効果が大きいものの、不満でな いセグメントでは効果がかなり小さく、重みづけす
ると、的中率 $79 \%$ 、尤度比0.2949となり、客観値と 比較すれば効果が大きい。

一方、セグメント別の予测シェアでは、いずれも $2 \%$ 以内のずれしかみられず、重みづけした予測シ エアでは、5つの指標のいずれも56\%台で、選択実 績の $56.8 \%$ に非常に近い値を示しており差異は認め られない。

説明力と予測シェアから判断すると、主観值によ るセグメント、特にサービス指標の重視度としての 遅れを重視するかどうかかの効果が大きい。

次に、客観値としての30才を区切りとした年令、 主観値としての遅れに対する重視度による、そ机ぞ れのセグメント別モデルを表 9 に示す。

年令については、30才末満のセグメントの方が地 下鉄のシェアが20\%程高く、30才以上のセグメント は地下鉄を敬遠していることが分かる。これは、地 下鉄駅まで歩くことが影響しているものと考えられ、 パラメータの比較でむ、30才以上のセグメントでは、 徒歩時間のパラメータの值が乗車時間などのパラメ 一夕の値と比べてかなり大きいのに対して、30才末 满のセグメントでは逆に徒歩時間のパラメータの方 が乗車時間よりも小さい。

主観值である遅れの重視についてのセグメントで は、セグメントによりシェアが $30 \%$ 異なり、パラ メー夕も大きく異なる。徒歩時間のパラメー夕につ

表 8. モデルの説明力と予測シェアからみたセグメントに用いる指標の比較

\begin{tabular}{|c|c|c|c|c|c|c|c|c|}
\hline & \multicolumn{3}{|c|}{ モデルの説明力(サンブル数) } & \multicolumn{3}{|c|}{ 地下鉄経路のシェア(サンプル数) } & \multirow{2}{*}{ 評価 } \\
\hline & & セグメント 1 & セグメント 2 & 全体 & セグメント 1 & セグメント 2 & 全体 & \\
\hline \multirow{2}{*}{ 客 } & $\begin{array}{c}\text { 性 別 } \\
\text { (女性／男性） }\end{array}$ & $\begin{array}{l}82.35 \%(68) \\
0.3614\end{array}$ & $\begin{array}{l}69.91 \%(226) \\
0.1782\end{array}$ & $\begin{array}{l}72.79 \% \\
0.2206\end{array}$ & $\begin{array}{l}67.43 \%(68) \\
67.65 \%\end{array}$ & $\begin{array}{l}53.42 \%(226) \\
53.54 \%\end{array}$ & $\begin{array}{l}56.66 \% \\
56.80 \%\end{array}$ & $\triangle$ \\
\hline & $\begin{array}{c}\text { 年 } \quad \text { 令 } \\
\text { (40才以上/40才末满) }\end{array}$ & $\begin{array}{l}65.65 \%(131) \\
0.1521\end{array}$ & $\begin{array}{l}76.07 \%(163) \\
0.2865\end{array}$ & $\begin{array}{l}71.42 \% \\
0.2266\end{array}$ & $\begin{array}{l}52.34 \%(131) \\
54.20 \%\end{array}$ & $\begin{array}{l}59.95 \%(163) \\
58.90 \%\end{array}$ & $\begin{array}{l}56.56 \% \\
56.80 \%\end{array}$ & $\triangle$ \\
\hline $\begin{array}{l}\text { 観 } \\
\text { 值 }\end{array}$ & $\begin{array}{c}\text { 年 } \quad \text { 令 } \\
\text { (30才以上/30才未満) }\end{array}$ & $\begin{array}{l}71.57 \%(204) \\
0.2196\end{array}$ & $\begin{array}{l}81.11 \%(90) \\
0.3625\end{array}$ & $\begin{array}{l}74.49 \% \\
0.2633\end{array}$ & $\begin{array}{l}50.66 \%(204) \\
50.98 \%\end{array}$ & $\begin{array}{l}69.26 \%(90) \\
70.00 \%\end{array}$ & $\begin{array}{l}56.35 \% \\
56.80 \%\end{array}$ & 0 \\
\hline \multirow{2}{*}{$\begin{array}{l}\text { 主 } \\
\text { 観 } \\
\text { 値 }\end{array}$} & $\begin{array}{c}\text { 地下鉄でない経路に不满 } \\
\text { (不満/不満でない) }\end{array}$ & $\begin{array}{l}80.70 \%(171) \\
0.3131\end{array}$ & $\begin{array}{l}77.24 \%(123) \\
0.2695\end{array}$ & $\begin{array}{l}79.25 \% \\
0.2949\end{array}$ & $\begin{array}{l}73.27 \%(171) \\
73.68 \%\end{array}$ & $\begin{array}{l}33.94 \%(123) \\
33.33 \%\end{array}$ & $\begin{array}{l}56.82 \% \\
56.80 \%\end{array}$ & (2) \\
\hline & $\begin{array}{c}\text { 遅れを重視する } \\
\text { (重視／重視しない) }\end{array}$ & $\begin{array}{l}81.63 \%(196) \\
0.3261\end{array}$ & $\begin{array}{l}78.57 \%(98) \\
0.3508\end{array}$ & $\begin{array}{l}80.43 \% \\
0.3343\end{array}$ & $\begin{array}{l}67.68 \%(196) \\
68.37 \%\end{array}$ & $\begin{array}{l}35.05 \% \text { ( } 98) \\
33.67 \%\end{array}$ & $\begin{array}{l}56.80 \% \\
56.80 \%\end{array}$ & (2) \\
\hline
\end{tabular}

注. モテルの説明力の上段は的中率、下段は $\rho^{2} 、$ 従来型モテルの的中率は71.43\%、 $\rho^{2}$ は0.2075

地下鉄経路のシェアの上段はセグメント別モデルの予测シェア、下段は実績、従来型モデルの予测シェアは $56.64 \%$ 
いて見ると、遅れを重視しないセグメントでは、遅 机を重視するセグメントに比べてかなり大きくなっ ている。

\section{5. まとめと今後の課題}

モデルの説明変数としての意識データの有効性と しては、設定值を用いた従来型モデルと比較して、 回答值モデル、評価值を加えたモデルの説明力が高 いことが示され、特に定性的要因を考慮できるとい う点で評価値の重要性が示された。しかしながら、 回答值モデル、評価値を加えたモデルでは、サンプ ルの数が従来型モデルの場合に比べてかなり減少す るため、調査の効率性や全体の誤差との関係などを 検討することが必要であり、また、評価値を予測す ることは困難なために、その適用の範囲は比較的に 短期の予測に限定される。

セグメントに用いる指標としては、客観值と比較 して主観値、特に、遅れを重視するかどうかという サービス指標の重視度では、説明力が大きく改善さ れ、セグメントによりパラメータが大きく異なるこ とが明らかとなったが、実際の予測作業においては 対象に応じてどの指標を用いてセグメントに分ける のが適切かを検討することが必要である。

最後に、適切なアドバイスを頂いた新谷教授を始 めとする研究室の皆様に心からの感謝の気持ちを記 します。

\section{参考文献}

1) 土木学会土木計画学研究委員会編 : 土木計画学 講習会テキスト 15 非集計行動モデルの理論と実 際、1984年

2）河上省吾・広畠康裕：利用者の主観的評価を考 慮した非集計交通手段選択モデル、土木学会論文 集第353号 $/ \mathrm{IV}-2 、 1985$ 年 1 月

3) Recker,W.W. and Golob,T.F.:An Attitudinal Modal Choice Model, Transportation Research Vol.10, pp.299-310, 1977

4) Tardiff,T.J.:Attitudinal Market Segmentation for Transit Design, Marketing and Policy Analysis, Tranportation Research Record 735, 1979

5) Koppleman,F.S. and Pas,E. I.:Travel-Choice Behavior:Models of Perceptions, Feelings, Preference and Choice, Transportation Research Record 765, 1980

6) Gensch,D.H. and Torres, P.T.:PerceivedDifference Segmentation Model for Mass Transit Marketing, Transportation Research Record 765, 1980

表 9. セグメント別モデルのパラメータの比較 [t-值 $]$

\begin{tabular}{|c|c|c|c|c|c|}
\hline & \multirow{2}{*}{ 従来型モデル } & \multicolumn{2}{|c|}{ 客観值によるセグメント別モデル } & \multicolumn{2}{|c|}{ 主観値によるセグメント別モデル } \\
\hline & & 30 才以上 & 30才末満 & 荤れを重視 & 遅れに無関心 \\
\hline $\begin{array}{c}\text { 料金 } \\
\text { 乗換・待ち時間 } \\
\text { 徒步時間 } \\
\text { バス乗車時間 } \\
\text { 鉄道乗車時間 }\end{array}$ & $\begin{array}{l}-0.0116[-2.56] \\
-0.1089[-2.20] \\
-0.2138[-5.23] \\
-0.1747[-6.45] \\
-0.1838[-4.65]\end{array}$ & $\begin{array}{l}-0.0266[-3.94] \\
-0.0280[-0.48] \\
-0.2352[-4.26] \\
-0.1420[-4.35] \\
-0.1411[-2.99]\end{array}$ & $\begin{array}{r}0.0059[1.18] \\
-0.2892[-2.44] \\
-0.2053[-2.86] \\
-0.2662[-4.36] \\
-0.2801[-3.39]\end{array}$ & $\begin{array}{l}-0.0279[-3.82] \\
-0.0633[-0.94] \\
-0.2067[-3.94] \\
-0.1760[-4.75] \\
-0.1219[-2.27]\end{array}$ & $\begin{array}{l}-0.0018[-0.43] \\
-0.1667[-1.71] \\
-0.3588[-3.71] \\
-0.1910[-3.61] \\
-0.2951[-3.54]\end{array}$ \\
\hline $\begin{array}{c}\text { 的中率 } \\
\rho^{2} \\
\text { サンブル数 }\end{array}$ & $\begin{array}{c}71.43 \% \\
0.2075 \\
294\end{array}$ & $\begin{array}{c}71.57 \% \\
0.2196 \\
204\end{array}$ & $\begin{array}{c}81.11 \% \\
0.3625 \\
90\end{array}$ & $\begin{array}{c}81.63 \% \\
0.3261 \\
196\end{array}$ & $\begin{array}{c}78.57 \% \\
0.3508 \\
98\end{array}$ \\
\hline $\begin{array}{l}\text { 予測シェア } \\
\text { 実綪シェア }\end{array}$ & $\begin{array}{l}56.64 \% \\
56.80 \%\end{array}$ & $\begin{array}{l}50.66 \% \\
50.98 \%\end{array}$ & $\begin{array}{l}69.26 \% \\
70.00 \%\end{array}$ & $\begin{array}{l}67.68 \% \\
68.37 \%\end{array}$ & $\begin{array}{l}35.05 \% \\
33.67 \%\end{array}$ \\
\hline
\end{tabular}

注. シェアはいずれむ地下鉄経路のシェア 